\title{
ST. EPHRAIM'S INFLUENCE ON THE GREEKS
}

\author{
DAVID G.K. TAYLOR \\ DEPARTMENT OF THEOLOGY \\ UNIVERSITY OF BIRMINGHAM \\ UNITED KINGDOM
}

[1] Attempting to identify the nature and extent of St. Ephraim's influence on the Greeks (by which term I designate simply those who wrote Greek, irrespective of their mother tongue or place of origin), is far from easy, despite the fact that there is no shortage of available materials which bear upon the subject. In addition to the numerous authentic Syriac writings which survive ${ }^{1}$ (Ephrem wrote exclusively in Syriac and is not thought to have known more than the bare rudiments of Greek), there are a number of accounts of the saint's life written in Greek and Syriac; a large collection of Greek writings attributed to him and conventionally termed "Ephraim Graecus;" and a variety of Greek writers of the $4^{\text {th }}$ to $6^{\text {th }}$ centuries with whom connections have been posited. The difficulty is that although a figure conventionally identified as St. Ephraim came to occupy a position of great importance and influence within the Greek-speaking Church, it is far from clear how this figure can be connected with the Syrian "Harp of the Spirit" and his genuine theological writings.

Of the various sources listed the biographical materials appear, at first glance, to offer the greatest potential. The earliest known allusion to Ephraim's work in a non-Syriac text is given by

${ }^{1}$ For a very useful survey of these cf. S.P. Brock, "A Brief Guide to the Main Editions and Translations of the Works of St. Ephrem," The Harp 3 (1990): 7-25. 
Epiphanios (fl. 377) in his Panarion, ${ }^{2}$ but the first reference with any biographical information is provided by Jerome in his De viris illustribus of AD 392, in which he notes; "Ephraim a deacon of the church at Edessa, wrote much in the Syrian language, and attained to such renown, that in some churches, after the reading of the scriptures, his writings are publicly recited." 3 Already by approximately 420 when the Lausiac History was written, that is within 50 years of Ephraim's death in 373, its author Palladios can open his chapter on Ephraim with the words "You must have heard particulars about Ephraim, the deacon of the church of Edessa...," 4 and is able to expand upon Jerome's bare statement with an account of Ephraim's activity during a famine in Edessa. Furthermore, he already has the Edessan deacon metamorphosing into a monk, and so has him living a solitary life in a cell. ${ }^{5}$ Theodoret $^{6}$ and Sozomen, ${ }^{7}$ both writing their ecclesiastical histories in the first half of the fifth century, build upon these materials, as does the pseudo-Amphilochian life of Basil, ${ }^{8}$ with its colourful account of the meeting of Basil and Ephraim in Cappadocia which leads to Basil ordaining Ephraim to the diaconate and Ephraim miraculously receiving that most blessed of

${ }^{2}$ K. Holl and J. Dummer (ed.), Panarion (GCS 31; Berlin, 1980²) 52.22.7.

${ }^{3}$ De viris illustribus 115, PL 23.745.

4 Chapter 40 of C. Butler (ed.), The Lausiac History of Palladius (Cambridge, 1904) 126; English translation by W.K.L. Clarke (London, 1918) 139.

${ }^{5}$ For a thorough analysis of the extant biographical sources and their reliable historical information, $c f$. B. Outtier, "S. Ephrem d'après ses biographies et ses oeuvres," PdO 4 (1973): 11-33.

6 L. Parmentier and F. Scheidweiler (ed.), Theodoret, Historia ecclesiastica (written post 429) (GCS 44; Leipzig, 1954) IV.26.

7 J. Bidez and G.C. Hansen (ed.), Sozomen, Historia ecclesiastica (written circa 443) (GCS 50; Leipzig, 1960) III.16.

${ }^{8}$ F. Combéfis (ed.), SS. Patrum Amphilochii Iconiensis, Methodii Patarensis et Andreae Cretensis opera omnia (Paris, 1644) 155-225; Syriac version, P. Bedjan (ed.), Acta Martyrum et Sanctorum VI (Paris, 1896) 297-334. A very useful survey and analysis is provided by O. Rousseau, "La Rencontre de S. Ephrem et de S. Basile," OrSyr 2 (1957): 261-84; 3 (1958): 73-90. 
divine gifts, knowledge of the Greek language. ${ }^{9}$ The later (circa 650) encomium on Ephraim attributed incorrectly to Gregory of $\mathrm{Nyssa}^{10}$ further expands the monastic and ascetic imagery associated with St. Ephraim.

As is well known to most scholars, the majority of the biographical details provided in these works are either legendary or, at best, untrustworthy. That, however, does not extinguish their interest for us. First it should be noted that these texts were all composed in Greek and the earliest of them not only predate but often subsequently influenced the Syriac vita tradition. This poses a very simple question; Why were they written? One obvious answer is that Ephraim's reputation and status was so great amongst the Greeks that there was a demand for such materials to satisfy their curiosity about the man. This admiration is well demonstrated by several 'purple passages' in the Pseudo-Gregory encomium just referred to; "Ephraim is the true universal doctor of the Church, who has attained the highest level on the ladder of spiritual virtues;"11 "Wherever the sun shines (Ephraim) is known, and he is only not known amongst those who are also ignorant of that great luminary of the Church, Basil;"12 and this wonderfully redolent text, "Ephraim is the mental Euphrates of the church, from whom the whole company of believers being watered, they produce a hundred-fold the fruit of faith."13 Again, in a treatise falsely attributed to John Chrysostom, the Sermo de Pseudoprophetis et falsis Doctoribus, ${ }^{14}$ the author bewails the lack of devout theologians in his age and provides a list of the great church fathers of the past, Evodius, Ignatius, Dionysius, Hippolytus, Basil, Athanasius, Gregory and Ephraim, to each of whom is given a few short words of praise; thus Evodius is the "fine fragrance of the church, and the successor and imitator of the apostles," Ignatius is "the dwelling

${ }^{9}$ Not to be outdone, one of the Syriac versions of the Acts of Saint Ephraim, T.J. Lamy (ed.), Sancti Ephraem Syri Hymni et Sermones, II (Malines, 1882) 5-90, also has Basil receive the gift of Syriac.

10 PG 46.819-50.

11 PG 46.828D.

12 PG 46.821D.

13 PG 46.824A.

14 B. de Montfaucon (ed.), Joannis Chrysostomi Archiepiscopi Constantinopolitani opera omnia quae exstant, vel quae ejus nomine circumferuntur (Paris, 1728) VIII (Spuria), 72ff. 
place of God," and Dionysius is "a bird of heaven." The list climaxes, however, with Ephraim who is described as "the arouser of the slothful, the consoler of the afflicted, the instructor of the young, the guide of the penitent; an arrow and javelin against heretics, a depository of virtues, and a habitation and resting place of the Holy Spirit." 15 From this it is clear that Ephraim's prestige in the Greek-speaking church should not be underestimated.

Returning now to the Pseudo-Amphilochian life of Basil with its account of the encounter between Basil and Ephraim, one can reasonably question the motives that produced this almost certainly fictitious meeting. Is it simply an attempt to tie up a pair of loose biographical strands: i.e. both fathers lived within easy travelling distance of each other, and both were engaged in combating Arianism and other heresies in the region, and so it stood to reason that they must have met at some point? Or is it, as some scholars have suggested, that a Greek-speaking Syrian sought to increase Ephraim's prestige by associating him with Basil? (Indeed Rousseau ${ }^{16}$ goes so far as to talk of "a sort of canonisation" of Ephraim by Basil.) Given the status that Ephraim already possesses in the passages cited above from Palladios and the early Greek lives and histories, this analysis does not seem persuasive. I would argue instead that the underlying purpose of this account is to bring Ephraim within the sphere of the Greek-speaking church. He is no longer an outsider, but is transformed into an insider. His life and writings become part of the patrimony of the Greek and orthodox church, distanced from any suspicion of foreign heresy (which from the fifth century on tainted the Greek view of most Syrians). This could be no more than an attempt by admirers to strengthen their links with one of the great heroes of the church, but the gift of Greek in particular could also be interpreted not as a condescending gift to a provincial Syrian, or as an attempt by a Syrian biographer to bestow posthumous cultural respectability upon his subject, but as an attempt to include Ephraim within the fold of the Greek-speaking theologians, rather than leave him as a notorious and disquieting example of a divine who was able to produce outstanding theology unhindered by possessing only 'tourist Greek'. Furthermore the receipt of this gift, and his

1579 C.

16 Op. cit., 89. 
diaconal orders, at the hands of Basil could then be construed as the clear subordination of the 'glory of the Syrians' to the great hellenising bishop of the age (with a concomitant enhancement of Basil's prestige). Whether, in the final analysis, one reads this text as strengthening Ephraim's bonds with the Greek-speaking church through friendly association and divine grace, or through hellenisation and ecclesiastical subordination, one can be left in no doubt of the admiration and respect that it accords to him.

The origin of this status lies not, primarily, in his ecclesiastical activities and way of life, but in his writings (though these of course are the product of, and mirror, that life). It is important, then, to provide an overview of the Greek corpus of writings attributed to Ephraim, although it should be noted that surprisingly little work has been done on this corpus, either in analysing its contents or in charting its development and expansion. For an early description of its contents one cannot do better than look at the relevant section of the Bibliotheca by Photios $^{17}$ (written 855-56). He mentions 49 discourses; the first describing the author's own life; the second an exhortation to his brothers living in community; the fourth is an initiation for those who undertake the monastic life, as are the next 19 ! The $25^{\text {th }}$ is an exhortation not to change monastic location, the $33^{\text {rd }}$ is an exhortation to chastity, and so on. Some of these texts have been identified with Greek writings in the great eighteenth-century Roman edition of Ephraim's works, ${ }^{18}$ yet not only do they have no discernible relation to the genuine extant Syriac texts of Ephraim, but they are clearly incompatible with such details of his life as are generally deemed trustworthy. (Ephraim was no coenobitic monk!) The Ephraim Graecus corpus eventually achieved a great size, ${ }^{19}$ and although a leading expert on these writings, Hemmerdinger-Iliadou, ${ }^{20}$ was able to identify some which were certainly of Syriac origin, or which apparently contained gospel citations from the Diatessaron, there is little evidence that 89-92.

${ }_{17}$ Cf. R. Henry (ed.), Photius: Bibliothèque, III (Paris, 1962) \$196 pp.

${ }^{18}$ J.S. Assemani, P. Mobarek, and S.E. Assemani, S. Ephraem Syri opera omnia quae exstant graece, syriace, latine, in sex tomos distributa (Rome, 1732-46).

${ }^{19}$ Cf. M. Geerard (ed.), Clavis Patrum Graecorum, II (Turnhout, 1974) 366-468.

${ }^{20}$ D. Hemmerdinger-Iliadou, "Éphrem (Les Versions): I. Éphrem grec. II. Éphrem latin,” DSp 4 (1960): 800-19. 
these were produced by Ephraim himself. Some of the writings attributed to him have been recognised as the work of other theologians, such as Pseudo-Macarius, ${ }^{21}$ Palladios, ${ }^{22}$ Isaac of Nineveh, ${ }^{23}$ and John Chrysostom, ${ }^{24}$ and some have features characteristic of a later period or a different place of origin. Indeed most scholars are doubtful whether any of the extant Greek corpus was translated from genuine works of Ephraim, with the possible exception of a homily on Jonah and the repentance of Nineveh. ${ }^{25}$

For devotees of Ephraim's writings this is hard to explain, although given that many of his Syriac hymns survive in a single manuscript it is possible that it is simply due to chance. The fact that much of his work consists of poetry rather than prose may also have been a contributory factor. It is clear, however, that both the translation into Greek of Syriac works ascribed to Ephraim, and the circulation of Greek works under his name, began at the earliest period. Sozomen, in the mid 5th century, states that his writings "were translated into Greek during his life, and translations are even now being made," 26 and Epiphanios in his Panarion $^{27}$ of 377 gives his approval to a piece of genuine Ephraimic exegesis now found in the hymn De Nativitate 5.13. Jerome however, in the text mentioned above, ${ }^{28}$ written in 392 , claims to have read a Greek version of Ephraim's work on the

21 E.g. De patientia, Assemani, op. cit., II.326C-334A = Homily B 55 of Pseudo-Macarius; De conversatione fratrum, III.314C-316 = Homily 3; Institutio ad monachos, III.324D-356A = the Epistola Magna.

${ }^{22}$ E.g. De domina Sala, II.393C-394 = Lausiac History ch. 34.

${ }^{23}$ E.g. De mansionibus beatis, III.25E-26A = PG 86.832B-833A.

${ }^{24}$ E.g. De oratione, III.455-458 = PG 48.743D-746D.

${ }^{25}$ For the Greek text cf. D. Hemmerdinger-Illiadou, "Saint Éphrem le Syrien: Sermon sur Jonas (Texte grec inédit)," Le Muséon 80 (1967): 4774, and for the Syriac text J.S. Assemani, op. cit. V.359D-387A, translated by $\mathrm{H}$. Burgess, The Repentance of Nineveh, a metrical homily on the mission of Jonah, by Ephraem Syrus (London, 1853). For a study of these cf A. de Halleux, "A propos du sermon éphrémien sur Jonas et la pénitence des Ninivites," in R. Schulz \& M. Görg (eds.), Lingua Restituta Orientalis: Festgabe für Julius Assfalg (Ägypten und Altes Testaments 20; Wiesbaden, 1990) 155-66.

${ }^{26}$ Sozomen, loc. cit.

27 Op. cit., 52.22.7. Cf. E. Beck, Ephräm der Syrer: Lobgesang aus der Wüste (Freiburg, 1967) 11.

${ }^{28}$ Cf. n. 2. 
Holy Spirit; "Legi ejus de Spiritu sancto graecum volumen, quod quidam de Syriaca lingua verterat; et acumen sublimis ingenii, etiam in translatione, cognovi." No treatise on this subject survives amongst Ephraim's Syriac writings, and Jerome's description of the work hardly encourages an identification with any of his hymns or verse homilies. The implication would thus seem to be that within a few decades of his death spurious Greek works were already being attributed to Ephraim. The early circulation of such spurious texts is also attested by citations in Greek writers from the 6th century on, as well as in several papyri.

Returning to the Greek vita tradition of St. Ephraim, I think it is now possible, given the nature of the Ephraim Graecus corpus, to suggest that the increasing emphasis on his ascetic and monastic lifestyle (following of course the Greek rather than the native Syrian pattern) is not just the result of writers conforming his life to familiar and expected models, but may actually reflect the nature of the corpus of Ephraim Graecus itself. The portrait was drawn and elaborated on the basis of the concerns and interests of the writings attributed to him. In other words, a human Ephraim Graecus has been produced who would be a credible author of the literary Ephraim Graecus. Both the Greek vita tradition and the Greek Ephraim corpus would thus appear to have early achieved an independent, self perpetuating existence. Although sparked off by Ephraim's reputation, in reality they had very little to do with him, and so it would be rather forced to argue that they represent Ephraimic influence on the Greeks. Of course, to the extent that Ephraim (like the seventh-century Isaac of Nineveh) was an archetypical Syrian ascetic for the Greeks and so was credited with numerous texts of Syriac origin which achieved great popularity, even becoming part of the prescribed readings during Lent, it is quite reasonable to claim that Ephraim Graecus represents a significant Syrian (even Syriac) influence upon the Greek church.

Ironically, just as Ephraim Graecus was created artificially from Greek ascetic works and the writings of minor Syriac authors as a result of the genuine Ephraim's reputation as the Syrian theologian par excellence, it seems quite possible that its continued authority and influence was in part bolstered by the honoured place that Ephraim Syrus and his genuine works continued to hold in the hearts of the Syriac-speaking churches. Thus the Palestinian born Sozomen, who grew up in a bilingual culture, is fulsome in his praise; 
"His style of writing was so replete with the splendid oratory and sublimity of thought that he surpassed all the writers of Greece. If the works of these writers were to be translated into Syriac, or any other language, and divested, as it were, of the beauties of the Greek language, they would retain little of their original elegance and value. The productions of Ephraim have not this disadvantage: they preserve much of their original force and power, so that his works are not less admired when read in Greek than when read in Syriac." ${ }^{29}$

The Egyptian Palladios, writing a couple of decades earlier (c. 420), is rather more reserved; "Also he left some writings, most of which deserve to be studied." 30 (The Syriac reads "Now he left behind him many books, and writings of various kinds, which were worthy of being preserved with the greatest care." ${ }^{1}$ )

With Photios, however, there is no hiding his puzzlement at reconciling the reverence of the Syriac-speakers for Ephraim's works with the poor quality Greek texts open before him:

"As for the words and figures, there is nothing surprising in seeing them slip towards rather common expression and colloquial laissez-faire; for responsibility for this does not lie with him who gave birth to these thoughts, but with him who translated them, for those who have a good appreciation of the Syriac language know that he excels in the use of words and figures to such a degree that one can hardly tell whether it is due to them or the Spirit that there is such a grace and power flowing from his writings. There is therefore, nothing surprising in the baseness of style, but what is surprising is that despite such vulgarity of expression, there is still for his adherents such a salvific and practical virtue to be found in them." 32

As book reviews go, this is distinctly barbed, and one cannot help but conclude that were it not for the praise of the Syrians Photios would have been deeply sceptical of the literary merits of

${ }^{29}$ Loc. cit.

${ }^{30}$ Op. cit., 40.4.

31 E.A.W. Budge, The Paradise of the Holy Fathers (London, 1907) Vol. I, 183.

32 Op. cit., 91 line $38 \mathrm{ff}$. 
Ephraim Graecus. On the other hand, it may have been precisely this tendency towards "common expression" and "baseness of style" rather than literary finesse that increased his popularity amongst his monastic readership.

It would thus appear that the influence of Ephraim Syrus on the Greeks is not to be found either in the Greek vita tradition nor in the Greek works circulated under his name. Nevertheless the interest and respect for St. Ephraim to which they bear witness encourages the thought that the theology and symbolism found in his genuine writings may have had an influence on Greek writers just as they did on his Syriac-speaking successors.

A number of likely candidates immediately come to mind. For example, Pseudo-Macarius, a fascinating figure who is no longer identified with the desert father St. Macarius of Egypt, but is thought to have written his fifty spiritual homilies in Mesopotamia, or possibly Asia Minor, in the 380s. ${ }^{33}$ Columba Stewart, in his detailed study of texts and terminology relating to the Messalian controversy, ${ }^{34}$ has clearly demonstrated the Syrian, and more specifically Syriac, background to many key items of vocabulary and imagery found in Pseudo-Macarius. Although, as might be expected, many parallels were found with the text of the Liber Graduum, numerous parallels were also found specifically in the writings of Ephraim. In addition to the ideas discussed by Stewart one might also mention the leitmotif of the robe of glory which covered Adam and Eve in Paradise, which is within Christians now, and which will finally be realised externally. ${ }^{35}$ Again, one

33 Cf. H. Dörries, Symeon von Mesopotamien. Die Überlieferung der messalianischen 'Makarios' Schriften (TU 55; Leipzig, 1941); H. Dörries, Die Theologie des Makarios-Symeon, (AAWG III.103; Göttingen, 1978); \& V. Desprez, "PseudoMacaire (Syméon)," DSp 10 (1977): 20-42.

34 C. Stewart, "Working the Earth of the Heart:" The Messalian Controversy in History, Texts, and Language to AD 431 (Oxford, 1991).

35 Cf. Homily 2.10-11, 5.8ff, 12.7-8, 20, 32.2, 34.4, 49.1, and compare the examples cited in S.P. Brock, "Clothing metaphors as a means of theological expression in Syriac tradition," in M. Schmidt (ed.), Typus, Symbol, Allegorie bei den östlichen Vätern und ibren Parallelen im Mittelalter (Eichstätter Beiträge IV; Regensburg, 1982) 11-38; and A. Kowalski, "Revestiti di gloria: Adamo ed Eva nel commento di S.Efrem a Gen2:25," Cristianesimo nella Storia, 3 (1982). 
might look at Pseudo-Macarius' developed spirituality of the heart and the parallels with this in Ephraim. ${ }^{36}$

Now, obviously, despite the impression to be gained from theological handbooks, Ephraim was not the only active Syriac theologian of the fourth century, and neither does he have a peculiar copyright on these ideas and imagery, but the possibility of actual influence on Pseudo-Macarius, rather than common heritage, needs to be explored. After all, it is clear that there were few barriers to theological contact in the region, for not only is it well known that Gregory of Nyssa reworked Macarius' Epistola Magna and circulated it in his De instituto christiano, ${ }^{37}$ but one of the leading Macarian scholars, Vincent Desprez, has argued convincingly that Macarius was strongly influenced by the Cappadocians. ${ }^{38}$

Indeed, having mentioned the Cappadocians, they would make a particularly interesting subject of study. I have argued elsewhere that Basil of Caesarea had strong political contacts with Syriacspeaking Christians in Syria and Mesopotamia, ${ }^{39}$ and it is well known that he twice explicitly cites the theological views of anonymous Syrians in his major writings ${ }^{40}$ (needless to say, tradition rapidly identified these with Ephraim, although few

${ }^{36}$ Cf. Homily 6.1, 8, 43, and compare S.P. Brock, "The prayer of the heart in Syriac tradition," Sobornost/Eastern Churches Review, 4:2 (1982): 131-42, and S.P. Brock, "The spirituality of the heart in Syrian tradition," The Harp, 1 (1988): 93-115.

${ }^{37}$ Cf. R. Staats (ed.), MakariosSymeon: Epistola Magna. Eine messalianische Mönchsregel und ibre Umschrift in Gregors von Nyssa "De instituto christiano" (AAWG III.134; Göttingen, 1984).

${ }^{38}$ V. Desprez, "Les Relations entre le PseudoMacaire et Saint Basile," in J. Gribomont (ed.), Commandements du Seigneur et libération évangélique (StAns 70; Rome, 1970) 20921. Cf. R. Staats, Gregor von Nyssa und die Messalianer (PTS 8; Berlin, 1968).

39 "Basil of Caesarea's Contacts with Syriac-speaking Christians," in E.A. Livingstone (ed.), Studia Patristica XXXII (Leuven, 1997) 204-10.

${ }^{40}$ In the Hexaemeron II.6 he refers to "a Syrian who was as ignorant in the wisdom of this world as he was versed in the knowledge of Truth," and in the De Spiritu Sancto XXIX.74.44 he mentions "a certain Mesopotamian, a man at once well skilled in the language and of unperverted opinions." On the former cf. J.R. Pouchet, "Les rapports de Basile de Césarée avec Diodore de Tarse," BLE 87 (1986): 26268, and L. van Rompay, "L'informateur syrien de Basile de Césarée: à propos de Genèse 1.2,” OCP 58 (1992): 245-51. 
contemporary scholars accept this). Together with Gregory of Nyssa, and later, most dramatically, Pseudo-Dionysius the Areopagite (who may well have been a Syrian of non-Chalcedonian origin and whose writings would also bear examination and comparison ${ }^{41}$ ) he also shares with Ephraim an interest in the theology of divine names. Since it was long thought impossible that an Athenian-educated sophisticate of Basil's calibre could have had anything to learn from the barbarous Syrians to the South, scholars have been reluctant to consider the possibility of Syrian influence, but I believe strongly that this does now need to be examined thoroughly.

An even stronger case can be made for examining Gregory of Nyssa's writings. Mention has already been made of his use of Pseudo-Macarius' Epistola Magna, and Staats has drawn attention to his reference to Mesopotamian ascetics in his homily In suam ordinationem. ${ }^{42}$ Sebastian Brock has also listed a number of shared themes and points of emphasis in common between Ephraim and Gregory (such as an emphasis on free-will, a sacramental view of the world, his use of light, mirror, and bridal imagery) although he does not go so far as to suggest that direct influence is at work here. ${ }^{43}$ This possibility does, however, in my opinion, need to be considered seriously.

That such studies can bear real, and not just hypothetical, fruit is shown by Bill Petersen's excellent monograph on Romanos the Melodist, ${ }^{44}$ the great sixth century Byzantine hymnographer who was also probably of bilingual Syrian stock. Not only did he demonstrate, as others have before, ${ }^{45}$ that Ephraim had a great influence on the development of the kontakion, but he also produced 22 examples of direct literary dependence-not just

${ }^{41}$ Cf. P. Rorem, Biblical and Liturgical Symbols within the Pseudo-Dionysian Synthesis (Toronto, 1984).

42 R. Staats, "Die Asketen aus Mesopotamien in der Rede des Gregor von Nyssa In suam ordinationem," VC 21 (1967): 165-79.

${ }^{43}$ S.P. Brock, The Luminous Eye: the Spiritual World Vision of St. Ephrem (Kalamazoo, 1992) 145ff.

${ }^{44}$ W.L. Petersen, The Diatessaron and Ephrem Syrus as Sources of Romanos the Melodist (CSCO 475; Louvain, 1985).

45 Cf. S.P. Brock, "Syriac and Greek Hymnography: Problems of Origin,” in E.A. Livingstone (ed.), Studia Patristica XVI (Berlin, 1985) 7781. and the references therein. 
'similar ideas' or expressions_-of Romanos on the Syriac works of Ephraim. Even if all other attempts at detecting Ephraim's influence on the Greeks were to fail, this literary bequest would by itself ensure that Ephraim Syrus' influence on Greek theology could never be overlooked. It should also encourage us to examine more closely the writings of such familiar authors as the Cappadocians, Pseudo-Dionysius, and Pseudo-Macarius and see whether beneath the overlay of Greek rhetoric there is a stratum that is dependent upon Ephraim, and not just the product of a common culture. 